\title{
MANAJEMEN SUMBER DAYA MANUSIADALAM PENINGKATAN KINERJA KRU PADA ORGANISASI QONAAH
}

\author{
Muhammad Ainul Fahmi, Syarifuddin \\ syarifuddinahm@gmail.com \\ Fakultas Syari’ah dan Ekonomi Islam Universitas Ibrahimy
}

\begin{abstract}
ABSTRAK
MSDM merupakan fokus yang sangat penting dalam pengembangan sebuah perusahaan untuk mencapai keunggulan yang kompetitif. Sumber Daya Manusia mempunyai peranan yang besar dalam suatu perusahaan atau organisai. MSDM menjadi pokok utama dalam setiap organisasi, termasuk organisasi Qona'ah. Organisasi qona'ah adalah organisasi yang bergerak dibidang literasi karya santri. Hingga saat ini organisasi tersebut telah berkembang menjadi organisasi yang kuat. Dalam penguantan kinerja Kru, organisasi qona'ah menggunakan beberapa langkah yang menjadi prinsip MSDM yaitu, perencanaan, pengorganisasian, pengarahan, pengawasan dan evaluasi.
\end{abstract}

Key word: MSDM, Peningkatan Kinerja KRU.

\section{PENDAHULUAN}

Perkembangan ekonomi menuntut pelaku bisnis untuk berperan aktif dalam menyikapi perkembangan tersebut, tentunya dengan sigap dalam mengambil tindakan dan tegas dalam menetapkan keputusan. Segala bentuk usaha mereka dirikan, berbagai macam barang yang diproduksi memberikan indikasi bahwamereka siap menghadapi persaingan.

Perusahaan berperan penting terhadap perkembangan tersebut, yaitu sebagai ladang produktivitas untuk menciptakan berbagai macam produk yang kreatif dan inovatif. Tujuan didirikannya suatu perusahaan adalah untuk meningkatkan nilai perusahaan melalui peningkatan kinerja karyawan. Karyawan memiliki kewajiban dalam melaksanakan pekerjaan yang telah ditetapkan oleh perusahaan, karena kinerja karyawan merupakan hasil kerja dari karyawan itu sendiri, baik kualitas maupun kuantitasnya sesuai dengan tanggung 
jawab yang diberikan perusahaan kepadanya. Kinerja juga bisa berarti hasil kerja yang dihasilkan atau disumbangkan karyawan berupa tugas dan tanggung jawab (Mangkunegara, 2010). Oleh karena itu, karyawan menjadi salah satu faktor jatuhbangunnya suatu perusahaan. Tanpa mereka, perusahaan tidak akan beroperasi dan berproduksi sehingga tidak dapat menghasilkan produk.

Begitu pentingnya kedudukan Sumber Daya Manusia pada suatu perusahaan sehingga menjadi titik acuan apakah perusahaan beroperasi dan berproduksi dengan baik atau tidak. Betapa pun besarnya bangunan dan modal yang digunakan serta matangnya rencana dan strategi, semua tidak akan berarti tanpa orang-orang yang melaksanakan melaksanakan rencana tersebut.

Manajemen Sumber Daya Manusia (MSDM) menganggap bahwa karyawan adalah kekayaan (asset) utama perusahaan. Kerana tanpa partisipasi mereka, aktivitas dan produktivitas perusahaan tidak akan terjadi. Karyawan berperan aktif dalam menetapkan sebuah rencana, sistem, proses, dan tujuan yang diinginkan bisa dicapai. Karyawan adalah penjual jasa (pikiran dan tenaga) dan berhak mendapat kompensasi yang besarnya sesuai dengan kesepakatan. Mereka berkewajiban mengerjakan pekerjaan yang diamanahkan kepadanya (H. Malayu S.P. Hasibuan, 2014).

MSDM merupakan fokus yang sangat penting dalam pengembangan sebuah perusahaan untuk mencapai keunggulan yang kompetitif. Sumber Daya Manusia mempunyai peranan yang besar dalam suatu perusahaan. MSDM harus dipandang sebagai perluasan dari pandangan tradisional untuk mengelola orang secara efektif dan oleh karena itu membutuhkan pengetahuan tentang perilaku dan sifat manusia serta kemampuan mengendalikannya (Edy Sutrisno, 2009).

Kinerja karyawan dapat ditingkatkan dengan beberapa cara, diantaranya melalui peningkatan kompensasi dan motivasi kerja. Dengan kompensasi yang diberikan perusahaan kepada karyawan, semangat, kemauan, dan ketelitian karyawan saat bekerja akan lebih maksimal, fokus, dan disiplin. Motivasi dan harapan karyawan untuk mendapatkan kompensasi yang sesuai membuat karyawan bekerja secara maksimal demi tercapainya kinerja yang baik.

Organisasi Qonaah merupakan organisasi yang beorientasi seputardunia baca-tulis 
(literasi). Karya para santri akan dimuat dan diterbitkan di Qonaah dalam bentuk Buletin (media baca seperti majalah). Di Pondok Pesantren Salafiyah Syafi'iyah Sukorejo terdapat beberapa media baca yang serupa, diantaranya Majalah Lembaga Pers Mahasiswa Ibrahimy yang diterbitkan oleh organisasi LPM Ibrahimy, Mediasi yang diterbitkan oleh organisasi IKSASS Pusat yang berlokasikan di Pusat, Tanwirul Afkar (TA) yang diterbitkan oleh organisasi TA yang berlokasikan di Asrama Ma'had Aly, Buletin AlKhidmat yang diterbitkan oleh organisasi Al-Khidmad yang berlokasikan di Asrama Ma'hadul Qur'an, dan di organisasi literatif lainnya di Pondok Pesantren Salafiyah Syafi'iyah Sukorejo.

Organisasi Qonaah tidak hanya menerbitkan karya berupa buletin, namun juga mencetak Mading Qonaah, Perpustakaan Qonaah, dan Quotes Qonaah. Buletin Qonaah, adalah sebuah buku hasil karya para santri yang tergolong tipis karena hanya memuat 20 halaman. Mading Qonaah, adalah media baca berupa informasi dan berita trending topic. Perpustakaan Qonaah, adalah sekumpulan buku bacaan seputar keilmuan dan keagamaan. Dan, Quotes Qonaah adalah rangkaian kata-kata atau dawuh para tokoh dan orang-orang besar.

Bisa dikatakan bahwa organisasi tersebut kini telah berkembang. Ditinjau dari lingkup internalnya, karyawan/ kru yang ada di organisasi tersebut yang awal mulanya tidak ada pelatihan dan sulitnya dalam memonitoring kru, seiring berjalannya waktu kini organisasi Qonaah memiliki beberapa program dalam mengembangkan Sumber Daya Manusia (SDM), diantaranya dengan pengadaan Road Show ke asrama-asrama, tadarus puisi, perpustakaan Qonaah, tersedianya fasilitas berupa komputer, dan lain sebagainya. Yang awalnya pemasaran terbatas pada ruang lingkup pondok pesantren dengan agen yang terdapat di pesantren tersebut, namun tidak memakan waktu lama pemasaran juga dilakukan di luar pesantren, yaitu di pesantren-pesantren cabang Sukorejo. Diantaranya Pondok Pesantren Abu Zairi (Tlogosari-Bondowoso), Pondok Pesantren Mikhrojul Ulum (Sumber Jambe-Jember), Pondok Pesantren Al-Furqon (Grujukan-Bondowoso), dan Pondok Pesantren Manbaul Ulum (Wonosari-Bondowoso). Dan faktor utama perkembangannya adalah dengan adanya Sumber Daya Manusia yang tinggi, antara loyalitas, solidaritas, dan kualitas. Sebuah perusahaan tidak akan mengalami 
perkembangan bila SDM-nya rendah. Maka, sangat dibutuhkan kru yang memiliki etos kerja yang tinggi serta kedisiplinan yang tinggi karena dengan baiknya kinerja karyawan/kru akan menciptakan hasil yang baik pula.

Oleh karena itu, peneliti tertarik untuk melakukan kajian secara mendalam terkait Manajemen Sumber Daya Manusia dalam peningkatan kinerja kru di organisasi Qonaah yang berada di Asrama Nurul Qoni' Pondok Pesantren Salafiyah Syafi'iyah Jln. KHR. Syamsul Arifin Dusun Sukorejo Desa Sumberejo Kecamatan Banyuputih Kabupaten Situbondo. Selain itu, mengetahui Manajemen SDM melalui analisis SWOT di organisasi tersebut. Adapun yang menjadi fokus penelitian ini adalah Bagaimana Implementasi Manajemen Sumber Daya Manusia dalam Peningkatan Kinerja Kru pada Organisasi Qonaah.

\section{KAJIAN TEORI}

\section{Pengertian Manajemen}

Manajemen berasal dari kata "to manage" dalam bahasa Inggris yang artinya mengurus, mengatur, melaksanakan dan mengelola (Faustino Cardoso Gomes, 2000). Manajemen adalah ilmu dan seni mengatur proses pemanfaatan sumber daya yang ada secara efektif dan efisien untuk mencapai suatu tujuan tertentu. Manajemen juga bisa diartikan sebagai suatu proses dimana sumber daya digunakan untuk memperoleh tujuan perusahaan. Proses tersebut (manajemen secara umum) terdiri dari perencanaan (palnning), pengorganisasian (organizing), penyusunan (staffing), pengarahan (directing), dan pengawasan (controlling) (M. Manullang, 2008).

George R. Terry Lestie W. Rue mengutip dari sebuah penjelasan tentang manajemen, bahwa manajemen pada dasarnya ialah suatu proses atau kerangka kerja yang melibatkan bimbingan atau pengarahan suatu kelompok ke arah tujuan organisasi. Bisa juga bermakna mengelola, yaitu mengelola sumber daya yang ada. Mengelola berasal dari kata "kelola" yang berarti mengerjakan, mengurusi, dan menyelenggarakan kegiatan, atau yang lebih dikenal dengan istilah manajemen (M. Anton Athoillah, 2010).

\section{Manajemen Sumber Daya Manusia}

Menurut Moses N. Kiggundu dalam Ambar Teguh Sulistyani dan Rosidah, menyatakan bahwa MSDM adalah pengembangan dan pemanfaatan karyawan dalam 
rangka agar tujuan tercapai dan sasaran individu, perusahaan, dan masyarakat tercapai (Ambar Teguh Sulistyani dan Rosidah, 2003).

Pengertian Manajemen Sumber Daya Manusia menurut beberapa ahli, diantaranya: Menurut Hall T. Douglas dan Goodale G. James, bahwa "Human Resource Management is the prosses through hican optimal fit is achieved among the employee, job organization, and environment so that empnoyees reach their desiret lefel of satisfaction and performance and the organization metts it's goalds" (Hall T. Ddougle. \& Jemes Goodle G, 1986). Manajemen Sumber Daya Manusia (MSDM) adalah suatu proses melalui kesesuaian optimal yang diperoleh antara pegawai, pekerjaan organisasi, dan lingkungan. Sehingga para pegawai mencapai tingkat kepuasan dan performansi yang mereka inginkan dan organisasi memenuhi tujuannya.

Ada empat landasan untuk mengembangkan manajemen menurut pandangan Islam, yaitu kebenaran, keterbukaan, dan keahlian, seorang pemimpin harus memiliki ke empat sifat utama itu agar manajemen yang dijalankan mendapat hasil yang maksimal. "Hal penting dalam manajemen berdasarkan pandangan Islam adalah harus ada sifat ri'ayah atau jiwa kepemimpinan. Di dalam Manajemen untuk kepemimpinan-kepemimpinan memiliki empat ciri Sumber Daya Insani dalam perspektif Islam:

\section{Shiddiq}

Shiddiq menurut bahasa adalah jujur atau benar. Sedangkan menurut istilah Shiddiq berarti memberikan sesuatu yang benar atau sesuai dengan pernyataan. Pemberitaan itu tidak terbatas dengan perkataan, akan tetapi juga dengan perbuatan seperti isyarat dengan tangan, anggukan dengan kepala, juga dengan sikap diam dan lain sebagainya. Jadi shiddiq (benar) itu terwujud dalam ucapan, niat, tekat, dan perbuatan (Abdul Halim Usman, 2015). Shiddiq menjadi landasan penting dalam kehidupan bermasyarakat, karena dalam masyarakat sangat diperlukan adanya saling percaya dan saling pengertian. Dalam bekerja, sifat shiddiq sangat dibutuhkan, baik oleh internal organisasi maupun eksternal organisasi. Orang-orang yang shiddiq akan mendapat tempat dalam kepemimpinan atau memegang amanah penting dalam jabatan di organisasi atau perusahaan.

\section{Amanah}

Amanah atau amanat merupakan unsur penting dan menentukan akan keberhasilan 
dan tidaknya seseorang dalam berusaha dan beramal, serta menentukan keberhasil dan tidaknya suatu bangsa dalam mempertahankan dan melestarikan hidup didunia. Dalam kehidupan sehari-hari banyak kita temukan adanya perbedaan yang nyata antara orang yang bersifat amanah dengan orang yang suka berkhianat. Orang yang bersifat amanah atau jujur selalu menjadi tempat kepercayaan, sandaran dalam kehidupan, menjadi terhormat dan disegani. Sedangkan orang yang bersikap khianat atau curang selalu menjadi bahan pembicaraan, tidak disenangi orang bahkan selalu dikucilkan dalam pergaulan. Sebagai akibat dari dua sikap yang saling bertentangan itu, terlihat bahwa orang yang bersifat amanah selalu berhasil dalam menggapai tujuan dan harapan dari usaha. Sedangkan orang yang bersifat khianat selalu mengalami kegagalan dalam mencapai tujuan dan harapan yang di inginkan (Veithzal Rivai, 2009). ${ }^{27}$

Dalam bekerja, prinsip amanah terkait dengan kepercayaan terhadap tugas dan tanggung jawab yang diemban, jabatan yang dimiliki, dan wewenang yang dimiliki, yang dilaksanakan dengan benar-benar.

\section{Tabligh}

Tabligh berasal dari kata kerja ballagha-yuballighu artinya menyampaikan. Sedangkan menurut istilah tabligh adalah menyampaikan ajaran-ajaran Islam yang diterima dari Allah SWT kepada ummat manusia agar dijadikan pedoman hidup supaya memperoleh kebahagiaan di duniadan akhirat. Dalam konsep Islam, tabligh merupakan salah satu perintah yang dibebankan kepada para Nabi utusan-Nya. Nabi Muhammad sebagai utusan Allah menerima risalah dan diperintahkan untuk menyampaikan kepada seluruh ummat manusia, yang selanjutnya tugas ini diteruskan oleh pengikut dan ummatNya. Orang yang menyampaikan ajaran-ajaran Islam disebut mubaligh. Dalam hal ini berkaitan dengan aspek yang berhubungan dengan kepandaian penyampai pesan dalam merangkai kata-kata yang tepat dan benar, yang mampu membuat lawan bicara terpengaruh.

\section{Fathonah}

Fathonah artinya cerdas. Allah SWT memberikan kecerdasan kepada Rasulullah SAW sehingga mampu menyampaikan ajaran Islam dengan baik dan mampu menghadapi berbagai problematika tantangan dan rintangan, dan mampu serta menjelaskan hal-hal 
yang ditanyakan oleh ummat, baik yang percaya maupun yang tidak dipercaya. Dengan sifat fathonah, yakni kecerdasan disertai ilmu yang luas, Rasulullah mampu menyampaikan Al- Qur'an dan menjelaskan seluruh kandungan atau isi Al-Qur'an yang tertuang dalam ratusan ribu Hadits, sehingga ummat menjadi mudah dalam memahami ajaran Islam yang disampaikan oleh Rasulullah Saw.

\section{Pengertian Kinerja}

Istilah kinerja berasal dari dari kata job performance dan actual performance yang berarti prestasi kinerja atau sesungguhnya yang dicapai oleh seseorang (Moeheriono, 2012). Dari sisi etimologis, Badudu merumuskan kinerja (Performance) yang berarti unjuk kerja. Dalam kamus bahasa Inggris, kata "performance" diterjemahkan dalam bahasa indonesia, berarti daya guna melaksankankewajiban atau tugas. Dalam etimologi lainnya, kinerja diartikan sebagai sesuatu yang dicapai, prestasi yang diperlihatkan atau kemampuan kerja (Undang Ahmad Kamaluddin dan Muhammad Alfan, 2010).

Secara terminologi, kata "kinerja" berasal dari terjemahan kata performance yang berarti penampilan atau prestasi. Kinerja (performance) adalah hasil dari fungsi pekerjaan selama satu periode dalam waktu tertentu. Pendidik bertanggung jawab memenuhi kebutuhan peserta didik, baik spiritual,intelektual, moral, estetika, maupun kebutuhan fisik. Kinerja dapat diartikan performance standart, yaitu daerah atau wilayah kerja jabatan atau unit perusahaan yang dapat diterima atau ditolak terkait dengan upaya pencapaian visi dan misi. Kinerja adalah hasil bersih atas terealisasinya tanggung jawab dari tugas yang diemban oleh seseorang atas amanah perusahaan.

Kinerja atau performance adalah hasil kerja yang dapat dicapai olehseseorang atau sekelompok orang dalam suatu organisasi sesuai dengan kewenangan dan tugas tanggung jawab masing-masing dalam upaya mencapai tujuan organisasi bersangkutan secara legal, tidak melanggar hukum dan sesui dengan moral maupun etika (Ismail Nawawi, 2013). Kinerja karyawan tidak hanya sekedar informasi untuk dapat dilakukan prosesi atau penetapan gaji bagi perusahaan. Akan tetapi bagaimana perusahaan dapat memotivasi karyawan dan mengembangkan satu rencanauntuk memperbaiki kemerosotan kinerja dapat dihindari.

Seseorang merupakan gabungan dari kemampuan, usaha dan kesempatan yang 
dapat diukur dari akibat yang dihasilkannya. Oleh karena itu kinerja bukan menyangkut karaktristik pribadi yang ditujukan oleh seseorang melalui hasil kerja yang telah dan akan diartikan sebagai kesuksesan dalam melakukan pekerjaannya. Ukuran kesuksesan masingmasing karyawan bergantung pada fungsi dari pekerjaan yang spesifik dalam bentuk aktivitas selama kurun waktu tertentu. Dengan kata lain, ukuran kesuksesan kinerja tersebut didasarkan pada ukuran yang berlaku dan disesuaikan dengan jenis pekerjaannya.

\section{Faktor-Faktor yang mempengaruhi Kinerja}

Menurut Robert L. Mathis dan John H. Jackson, faktor-faktor yangmempengaruhi kinerja individu tenaga kerja yaitu (Hendi Suhendi dan Sahya Anggara, 2010):

\section{Kemampuan}

Secara psikologis, kemampuan terdiri dari kemampuan potensi (IQ) dan kemampuan reality. Artinya pimpinan dan karyawan yang memiliki IQ diatas rata-rata dengan pendidikan yang memadai untuk jawabannya dan terampil dalam mengerjakan pekerjaan sehari-hari. Maka akan lebih mudah mencapai kinerja maksimal.

\section{Motivasi}

Motivasi diartikan sebagai suatu sikap (Attitude) pimpinan dan karyawan terhadap situasi kerja dilingkungan organisasinya. Mereka yang bersikap positif terhadap situasi kerjanya akan menunjukkan motivasi kerja tinggi, dan sebaliknya jika mereka bersifat negatif terhadap situasi kerjanya akan menunjukkan motivasi kerja yang rendah. Situasi kerja yang dimaksud mencakup antara lain hubungan kerja, fasilitas kerja, iklim kerja, kebijakan pemimpin, pola kepemimpinan kerja dan kondisi kerja.

\section{Penilaian Kinerja}

Evaluasi kinerja (Performance evaluation) dalam organisasi publik merupakan peranan kunci dalam mengembangkan pegawai dan produktivitas mereka. Evaluasi kinerja pada prinsipnya merupakan manivestasi dari bentuk penilaian kerja seseorang pegawai dan sekaligus dapat memberikan feedback. Pada prinsipnya penilaian kinerja adalah merupakan cara pengukuran kontribusi-kontribusi dari individu dalam instansi yang dilakukan terhadap organisasi. Nilai penting dari penilaian kinerja adalah menyangkut penentuan tingkat kontribusi individu atau kinerja yang diekspresikan dalam penyelesaian tugas-tugas yang menjadi tanggung jawabnya. 
Penilaian kinerja sangat bermanfaat bagi pertumbuhan organisasi secara keseluruhan. Melalui penilaian tersebut maka dapat diketahui bagaimana kondisi rill karyawan dilihat dari kinerja. Dengan demikian data-data ini dapat dijadikan sebagai bahan pertimbangan dalam mengambil keputusan baik pada level makro organisasi maupum pada level mikro individual. Pengukuran kinerja merupakan suatu proses penilaian kemajuan pekerjaan terhadap pencapaian tujuan dan sasaran yang telah ditentukan. Dalam hal ini

penting untuk ditentukan apakah tujuan pengukuran adalah untuk menilai hasil kinerja (performance outcome) ataukah menilai perilaku (personality). Pengukuran kinerja paling tidak harus mencakup tiga variabel penting yang harus dipertimbangkan yaitu: perilaku output (produk langsung suatu aktivitas/program) dan outcome (dampak aktivitas). Perilaku hasil dan nilai tambah, merupakan variabel yang tidak dapat dipisahkan dan saling tergantung satu dengan yang lainnya (Mahmudi, 2005).

\section{Peningkatan Kinerja}

Kemauan keras (azam) ini dapat menggerakkan motivasi bila hasil evaluasi kinerja menunjukka kinerja seseorang rendah atau dibawah setandar yang telah ditetapkan, maka orang yang bersangkutan dan atasannya akan segera membuat segala upaya untuk meningkatkan kinerja tersebut, misalnya dengan bekerja lebih keras dan tekun. Untuk itu, setiap pekerja perlu menyadari dan memiliki: Kemampuan tertentu sebagai dasar untuk mengembangkan diri lebih lanjut, Keinginan untuk terus belajar dan meningkatkan kemampuan bekerja, Sikap tertarik pada pekerjaan dan etos kerja yang tinggi dan Keyakinan untuk berhasil (Payaman J. Simanjutak, 2005)

\section{METODE PENELITIAN}

Metode Penelitian pada dasarnya merupakan cara ilmiah untuk mendapatkan data, dengan tujuan dan kegunaan tertentu. Data yang diperoleh melalui penelitian tersebut adalah data empiris (berdasarkan pengalaman) yang mempunyai kriteria tertentu, yaitu valid. Valid menunjukkan derajat ketepatan antara data yang sesungguhnya terjadi pada obyek (nyata) dengan data yangdikumpulkan oleh peneliti (Sugiono, 2018). Peneliti dalam penelitian ini bisa dikatakan sebagai pengumpul data dan instrumen aktif dalam upaya mengumpulkan data-data di lapangan. Oleh karena itu, kehadiran Peneliti secara langsung dilapangan menjadi tolak ukur keberhasilan dalam memahami kasus yang diteliti, sehingga 
keterlibatan peneliti secara langsung disertai dengan sumber data sangat diperlukan. Lokasi penelitian yang dipilih oleh peneliti yaitu Organisasi Qonaah di Asrama Nurul Qoni Pondok Pesantren Salafiyah Syafi'iyah Sukorejo Desa Sumberejo Kecamatan Banyuputih Kabupaten Situbondo. Lokasi tersebut dipilih karena melihat banyaknya para santri yang aktif di dunia literasi dan antusias terhadap kegiatan yang diprogramkannya.

Penelitian ini bersifat deskriptif, maka penelitian ini mencoba untuk menjelaskan tentang penerapan Sumber Daya Manusia sebagai langkah utama untuk meningkatkan profitabilitas. Sumber data pada penelitian ini terdiri dari sumber data primer dan data sekunder. Data primer adalah data dalam bentuk verbal atau kata-kata yang diucapkan secara lisan dan gerak-gerik atau perilaku yang dilakukan oleh subjek yang dapat dipercaya. Dalam hal ini adalah subjek penelitian (informasi) yang berkenaan dengan variabel yang diteliti (Cholid Narbuko dan Abu Achmadi, 2015). Sedangkan data sekunder adalah Data seknder adalah data yang diterbitkan atau yang digunakan oleh organisasi/ perusahaan yang bukan pengelolanya. Teknik pengumpulan data dalam penelitian ini adalah mengunakan teknik observasi, wawancara dan dokumentasi. Setelah data-data penelitian terkumpul, peneliti melakukan pengecekan ke absahan data dengan cara menyajikan data, mereduksi serta memberikan kesimpulan.

\section{HASIL DAN PEMBAHASAN}

Manajemen Sumber Manusia yang diterapkan di Organisasi Qonaah di masa adalah dengan senantiasa disiplin, tingginya loyalitas, integritas, dan totalitas dalam bekerja. Manajemen SDM sangat lah penting bagi organisasi Qonaah dalam meningkatkan kinerja kru agar berjalan sesuai dengan keinginan organisasi. Maka dari itu, perusahaan/ organisasi bisnis harus sealu berupaya untuk mengembangkan manajemen SDM melalui: Perencanaan, Pengorganisasian, Pengawasan, Motivasi, dan Evaluasi haruslah diperhatikan dengan penuh kesungguhan agar kinerja kru meningkat.

\section{Perencanaan}

Menurut Pimpinan Redaksi, perencanaan sangat penting sebabtanpa perencanaan maka kinerja kru tidak akan berjalan efektif dan efisien. Organisasi Qonaah pastinya memiliki keinginan agar kinerja kru baik dan sesuai harapan.

Sesuai dengan hasil wawancara, perencanaan dalam Qonaah ialahmenempatkan kru 
di bagian yang sesuai dengan bakat dan kemampuannya. Dalam hal perencanaan pimpinan redaksi membuat peta pimikiran masa depan dengan cara belajar dari pengalaman dari beberapa organisasi yang lainnya.. Berdasarkan dengan teorinya bahwa perencanaan adalah merencanakan tenaga kerja secara efektif dan efisien dengan tujuan agar sesuai dengan kebutuhan perusahaan. Apabila sebagian kru masih kurang disiplin dan kurang teliti dalam kinerjanya, maka dengan demikian organisasi Qonaah perlu memberikan pemahaman tentang tugas apa saja yang seharusnya dilaksanakan (job description) dan mengadakan beberapa pelatihan.

\section{Pengorganisasian}

Pengorganisasian yang diterapkan di organisasi Qonaah bersifat relatif tergantung pada kebutuhan di bagiannya masing-masing. Sebagaimana dalam wawancara bahwa kru akan ditempatkan di bagian yang mereka sehingga bisa menjalankan tugas sesuai dengan jobnya. Dan, harus adanya skill dalam setiap job kerja maka dibentuk lah struktur organisasi. Untuk meningkatkan mutu organisasi qona'ah maka setiap pengurus diberikan pelatihan serta pemahaman dan job diskripsi dari tugas pokok masing-masing kru.

Berdasarkan teorinya, pengorganisasian diartikan suatu proses pengelompokan berbagai aktivitas yang diperlukan untuk mencapai suatu tujuan. Pengorganisasian dapat dilakukan dengan menempatkan karyawan sesuai dengan bidang keahlian. Apabila terjadi sebuah kesalahan dalam pelaksanaan tugas disebabkan ketidakmampuan kru dalam menjalaninya, maka dengan demikian organisasi Qonaah harus selektif dalam penyeleksian dan mengetahui kemampuan (bakat/skill) yang dimiliki masing-masing kru.

\section{Pengarahan}

Pengarahan yang diterapkan di organisasi Qonaah berpedoman pada aturan yang dibuat oleh organisasi tersebut. Setiap kru memiliki kewajiban menjalankan tugas sesuai dengan jobnya masing-masing. Dan, para kru diberikan beberapa faktor pendukung berupa fasilitas-fasilitas seperti buku panduan EYD, buku Desain, pengadaan Diklat Jurnalistik, dan lain-lain. Berdasarkan teorinya bahwa pengarahan dapat didefinisikan sebagai keseluruhan proses pemberian dorongan bekerja kepada para bawahan sedemikian rupa sehingga mereka mau bekerja dengan suka rela demi tercapainya tujuan organisasi dengan efesien dan ekonomis. Seperti yang terjadi di lapangan, kru terkadang masih kurang teliti 
dan sulit mengatur waktu dalam melaksanakan tugas terlebih di masa pandemi saat ini membuat kru terkadang menemukan dan merasakan kejenuhan. Maka dengan demikian organisasi Qonaah perlu lebih memprioritaskan dorongan terhadap kru agar mau menjalankan tugasnya dan bisa selesai tepat waktu.

\section{Pengawasan}

Pengawasan yang diterapkan di organisasi Qonaah berupa catatan kerja kru yang dipantau langsung oleh Pimpinan Redaksi, dan seharusnya tumbuh kesadaran dari setiap kru agar bisa saling tegur sapa diantara satu dengan yang lain. Apabila terjadi kesalahan maka terpaksa pimpinan turun tangan. Pengawasan dapat diartikan sebagai proses monitoring kegiatan- kegiatan, tujuannya untuk menentukan harapan-harapan yang akan dicapai dan dilakukan perbaikan-perbaikan terhadap penyimpangan-penyimpangan yang terjadi. Harapan-harapan yang dimaksud adalah tujuan-tujuan yang telah ditetapkan untuk dicapai dan program-program yang telah direncanakan untuk dilakukan dalam priode tertentu. Tujuan utama daripengawasan ialah mengusahakan agar apa yang direncanakan menjadi kenyataan.

Dari data di atas, peneliti menyatakan bahwa pengawasan yang diterapkan sudah cukup baik dan membantu dari keteledoran karyawan untuk saling menegur dan sekaligus memperbaiki diantara satu dengan yanglain. Apabila setiap kru memiliki kesadaran, ketika dia tidak aktif maka dia pun harus menyadari bahwa ketidakaktifannya akan menjadi kendala bagi kru yang lain. Dengan demikian, organisasi Qonaah khususnya pimpinan perlu memberikan nasehat dan arahan kepada bawahan agar terciptanyakinerja yang baik.

\section{Motivasi (Motivating)}

Motivasi yang diterapkan di organisasi Qonaah ialah dengan menyediakan sarana dan prasarana yang dibutuhkan berupa buku, tape recorder, kamera, komputer, kantor khusus, id card, dan jas almamater Motivasi di organisasi Qonaah sudah cukup baik karena telah diberlakukan suatu dorongan kepada kru untuk memicu semangat dalam bekerja, disamping itu sebenarnya sangat dibutuhkan kru yang bisa mendorong dirinya untuk bisa lebih semangat dalam bekerja. Berdasarkan teori, motivasi adalah karakteristik psikologi manusia yang memberi kontribusi pada tingkat komitmen seseorang. Motivasi termasuk faktor-faktor yang menyebabkan, menyalurkan, dan mempertahankan tingkah laku 
manusia dalam arah tekad tertentu. Motivasi yang dilakukan pada organisasi Qona'ah tidak hanya motivasi kerja saja akan tetapi ada motivasi ruhaniah berupak peningkatan nilai-nilai ibadah dan ikhlas beramal terhadap organisasi Qona;ah.

Dari semua data di atas, peneliti menyatakan organisasi Qonaah sudah memberi motivasi kepada setiap karyawan dengan baik, juga telah memfasilitasi dan memberikan segala kebutuhan yang diperlukan sehingga dapat memicu semangat bekerja bagi yang masih tergolong malas. Adapun motivasi terbesar yang menjadi pedoman bagi kru qona'ah adalah motivasi tentang pengabdia. Bahwa ada nilai barokah dari pengabdian yang dilakukan oleh kru. Bekerja merupakan amanah yang diberikan oleh allah dan harus digunakan dengan sebaik-baiknya.

\section{Evaluasi (evaluating)}

Evaluasi yang diterapkan di organisasi Qonaah ialah dengan memperhatikan beberapa aspek, baik secara tertulis maupun di lapangan. Evaluasi dilakukan secara berkala. Ada beberapa macam evaluasi yang digunakan oleh organisasi qona'ah, diantaranya adalah evaluasi kedisiplinan Kru, evaluasi kinerja Kru dan evaluasi keikutsertaan Kru. Evaluasi tersebut dilakukan setiap saru bulan satu kali dan dilakukan di minggu pertama awal bulan.

Berdasarkan teorinya bahwa setiap perusahaan yang berbasis bisnis pastinya memiliki program dalam mengevaluasi dari setiap kinerja karyawan, yaitu dengan memperhatikan dari absensi rapat atau absensi kerja. Jadi setiap bulannya ada laporan hasil kerja dari masing-masing karyawan dengan begitu perusahaan mudah untuk melakukan evaluasi kepada setiap karyawan Bagi peneliti, evaluasi sangat membantu organisasi dalam meningkatkan kinerja kru, dengan evaluasi yang dilakukan perusahaan dapat mengukur tingkat keberhasilan suatu organisasi.

\section{KESIMPULAN}

Setelah peneliti memaparkan data dari hasil penelitian dan melakukan analisis terhadap data-data tersebut dengan berdasarkan teori yang ada maka hasil penelitian dapat disimpulkan sebagai berikut: Qonaah merupakan sebutan organisasi yang bertempat di Asrama Nurul Qoni' Pondok Pesantren Salafiyah Syafi'iyah Sukorejo Desa Sumberejo Kecamatan Banyuputih Kabupaten Situbondo. Organisasi Qonaah merupakan organisasi 
yang bersifat yang bergerak di bidang literasi (baca-tulis) atau sebagai media untuk menyampaikan pesan maupun maksud baik yang bertujuan sebagai sarana dakwah. Selain dari hasil kinerja dari setiap kru, perusahaan/ organisasi bisnis harus selalu berupaya untuk mengembangkan Manajemen SDM melalui: perencanaan, pengorganisasian, pengarahan, pengawasan, motivasi, dan evaluasi.

\section{DAFTAR PUSTAKA}

Abdul Halim Usman. (2015). Manajemen Strategis Syari'ah. Jakarta: Zikrul Hakim.

Ambar Teguh Sulistyani dan Rosidah. (2003). Manajemen Sumber Daya Manusia. Yogyakarta : Graha Ilmu.

Cholid Narbuko dan Abu Achmadi. (2015). Metode Penelitian. Jakarta: Bumi Aksara.

Edy Sutrisno. (2009). Manajemen Sumber Daya Manusia. Jakarta: Kencana Prenada Media Group.

Faustino Cardoso Gomes. (2000). Manajemen Sumber Daya Manusia. Yogyakarta: Andi Offset.

H. Malayu S.P. Hasibuan. (2014). Manajemen Sumber Daya Manusia. Jakarta: PT Bumi Aksara.

Hall T. Ddougle. \& Jemes Goodle G. (1986). Human Resources Manajemen, Strategy, Desige and Implementasi. Glenview: Scoot Foresmen and Company.

Hendi Suhendi dan Sahya Anggara. (2010). Perilaku Organisasi. Bandung: Pustaka Setia.

Ismail Nawawi. (2013). Budaya Organisasi, Kepemimpinan, dan Kinerja. Jakarta : Prenada Media Group.

M. Anton Athoillah. (2010). Dasar-Dasar Manajemen. Bandung: Pustaka Setia.

M. Manullang. (2008). Pengantar Bisnis. Yogyakarta: Gadjah Mada University Press.

Mahmudi. (2005). Manajemen Kinerja Sektor Publik. Yogyakarta: UPP AMP YKPN .

Mangkunegara. (2010). Evaluasi Kinerja SDM. Bandung: Refika Aditama.

Moeheriono. (2012). Pengukuran Kinerja Berbasis Konpetensi. Jakarta: PT. Raja Grafindo Persada.

Payaman J. Simanjutak. (2005). Manajemen dan Evaluasi Kinerja. Jakarta : Fakultas Ekonomi Universitas Indonesia. 
Sugiono. (2018). Metode Penelitian Kuantitatif, Kualitatif, dan $R \& D$. Bandung: Alfabeta.

Undang Ahmad Kamaluddin dan Muhammad Alfan. (2010). Etika Manajemen Islam. Bandung : Pustaka Setia.

Veithzal Rivai. (2009). Islamic Human Capital, Edisi I. Jakarta: Rajawali Press. 